\begin{tabular}{|c|c|c|}
\hline$\left(\int_{\text {SiliRT }}^{\prime}\right.$ & $\begin{array}{c}\text { Türkiye Tarımsal Araştırmalar Dergisi } \\
\text { dergipark.gov.tr/tutad }\end{array}$ & $\begin{array}{l}\text { Turk J Agric Res } \\
\text { 2019, 6(1): 115-122 } \\
\text { ○ TÜTAD } \\
\text { ISSN: 2148-2306 }\end{array}$ \\
\hline $\begin{array}{l}\text { UNNIVERSiTESI } \\
\text { Bulimin Isüumda }\end{array}$ & Derleme / Review & $\begin{array}{l}\text { e-ISSN: } 2528-858 X \\
\text { doi: } 10.19159 / \text { tutad.475123 }\end{array}$ \\
\hline
\end{tabular}

\title{
Organik Kaba Yem Üretiminde Yabancı Otlarla Mücadele
}

\author{
Özlem ÖNAL AŞCI ${ }^{1 *}$, Zeki ACAR ${ }^{2}$ \\ ${ }^{1}$ Ordu Üniversitesi, Ziraat Fakültesi, Tarla Bitkileri Bölümü, Ordu, TÜRKIYE \\ ${ }^{2}$ Ondokuz Mayls Üniversitesi, Ziraat Fakültesi, Tarla Bitkileri Bölümü, Samsun, TÜRKIYE
}

\begin{tabular}{|c|c|}
\hline Geliş Tarihi/Received: 26.10 .2018 & Kabul Tarihi/Accepted: 01.02.2019 \\
\hline \multicolumn{2}{|l|}{ ORCID ID (Yazar surasuna göre / by author order) } \\
\hline (1D) orcid.org/0000-0002-9487-9444 (1) 0000-0002-0484-1961 & \\
\hline
\end{tabular}

Öz: Organik ruminant yetiştiriciliğinde, organik tarımda üretilmiş kaliteli kaba yemlere çok büyük ihtiyaç duyulmaktadır. Kaliteli kaba yem üretimini olumsuz etkileyen faktörlerden birisi de yabancı otlardır. Bu çalışma, organik kaba yem üretiminde yabancı ot mücadelesi hakkında bilgi sunmak amacıyla hazırlanmıştır. Organik tarımda kimyasal kullanımına izin verilmediğinden, yabancı otlarla mücadelede herbisit kullanma şansı kalmamaktadır. Bu nedenle yabancı otlar farklı yöntemlerle baskılanmalıdır. Bilindiği üzere, kaliteli kaba yemler çayır mera alanlarından ve yem bitkileri tarımından elde edilmektedir. Yem bitkileri tarımında ilk olarak yabancı otlardan arındırılmış tarlaya ekim yapmak ve kaliteli tohumluk kullanmak gerekmektedir. Ön bitki olarak tahıl veya çapa bitkisi yetiştirilmiş tarlalarda yem bitkisi ekildiğinde, yabancı otlar daha az problem olmaktadır. Cok yıllık türlerde arkadaş bitki ile birlikte ekim de yabancı ot kontrolünde etkili olmaktadır. Meralarda ise öncelikle otlatma yönetim ilkelerine uyulması ve otlatma planlaması ile yabancı otlar kontrol altında tutulabilir. Bunun yanı sıra bazı mera ıslah yöntemleri de yabancı otlarla mücadelede etkili olabilmektedir.

Anahtar Kelimeler: Yem bitkisi, mera, otlatma, organik tarım

\section{Weed Control in Organic Roughage Production}

\begin{abstract}
In organic ruminant product system, high quality hay, produced in organic agriculture, is a great need. One of the factors that negatively affect quality of roughage production is weeds. This study was prepared to provide information about the weed control in organic roughage production. Because chemical herbicide use in organic farming is not allowed, there is no chance to use herbicide to control weeds. Therefore, weeds should be suppressed by different methods. As known quality roughage is obtained from meadow-pasture lands and forage crops grown in field. In the forage crops agriculture, first of all, it is necessary to sow to the field free of weeds and to use high quality seed. When forage plants were sown at the field where cereal or hoe plants was grown as previous crop, weeds are less problem. In the perennial species, planting with a companion crop is also effective in weed control. In pasture lands, weeds can be controlled with following grazing management principles and grazing planning. In addition, some pasture improvement methods can be effective in combating weeds.
\end{abstract}

Keywords: Forage plant, pasture, grazing, organic farming

\section{Giriș}

Organik hayvanc1lıkta, hayvan beslemede kullanılacak yemlerin, organik ve özellikle bitkisel kaynaklı olması gerekmektedir. Organik bitkisel kaynaklı yemlerin üretiminde GDO (Genetiği değiştirilmiş organizma)'lu tohumlar, sentetik kimyasal gübreler, tarım ilacı ve büyüme düzenleyiciler (hormon) kullanılamaz (Özen ve ark., 2010).

Büyükbaş ve küçükbaş hayvan yetiştiriciliğinde kaliteli kaba yemler, rasyonlarda çok önemli yer tutmaktadır. Kaliteli kaba yemler çayır mera alanlarından ve tarla tarımı içerisinde yetiştirilen yem bitkilerinden elde edilmektedir. 
Tarım ve Orman Bakanlığı'nın organik üretim verileri incelendiğinde, 2017 yılında; silajlık misır, yonca, yaygın fiğ, macar fiği, yem pancarı, korunga, İtalyan çimi, yem bezelyesi, yem şalgamı, üçgül, burçak, mürdümük, sudan otu bitkilerinde organik yetiştiriciliğin yapıldığg görülmektedir. Bunların dışında çayır otu, yapay çayır mera, nadas olarak ifade edilen üretim değerleri belirtilmektedir. Aynı verilerde arpa, yulaf, tritikale ve çavdarın da organik olarak üretildiği göze çarpmaktadır. Bu verilerden net olarak organik kaba yem üretimini hesaplamak mümkün olmamaktadır. Şöyle ki; yaygın fiğ, macar fiği, yem bezelyesi, burçak, mürdümük, arpa, yulaf, tritikale ve çavdarda üretim değerlerinin ot mu yoksa tohum mu olduğu belirtilmemiştir. Organik tarım yapılan alan da belirtilmediği için üretim değerlerinin ot veya tohum verimi olduğunu anlama şansı bulunmamaktadır. Yine arpa, yulaf, tritikale ve çavdarın hayvan yemi olarak mı yoksa gıda amaçlı $\mathrm{m} 1$ değerlendirildiğine dair bir bilgi bulunmamaktadır. Tüm bu nedenlerle arpa, yulaf, tritikale, çavdar, sorgum hariç diğer türlerin tamamında ot üretimi yapıldı̆̆ı varsayılmıştır. Çayır otu, yapay çayır mera üretimi ve yem bitkisi üretimi değerleri dikkate alındığında, 2017 yılında yaklaşık 412.499 ton kaba yem üretimi yapıldı̆̆ hesaplanmıştır. En fazla üretimi yapılan bitkiler ise yonca ve korunga olmuştur (Anonim, 2018). Türkiye'de en fazla organik yem bitkisi üretimi Erzurum, Van, Kars, Ağrı, Muş, Sivas, Ardahan, Bitlis, Çanakkale, Bayburt, Erzincan, İzmir, Ankara, Tunceli ve Iğdır'da yapılmaktadır (Açıkbaş ve ark., 2017).

Türkiye'de mera alanları halkın ortak kullanımında olduklarından buralardan hangi ölçüde organik hayvancılıkta faydalanıldığına dair bir bilgiye de ulaşılamamıştır. Ancak Türkiye'de daha önce de değinildiği üzere mera alanları ortak kullanıldığından, Bakanlık tarafindan ıslah çalışmasına dâhil edilmeyen bütün meralarda hiçbir bakım işleminin (gübreleme, yabancı ot mücadelesi vb.) yapılmadığ 1 bilinmektedir. $\mathrm{Bu}$ yönüyle değerlendirildiğinde Türkiye meralarının neredeyse tamamının organik tarıma uygun olduğunu söyleyebiliriz. Nitekim organik hayvancılığın Doğu Anadolu Bölgesi'nde yaygın olması, bu bölgede geniş yer tutan mera alanlarının organik hayvancılıkta kullanıldığına işaret etmektedir. İster doğal, ister yapay olsun mera alanları organik hayvancılıkta hem kaba yem kaynağı olması, hem de hayvan refahı bakımından büyük öneme sahiptir. Nitekim organik tarım yönetmeliğinde (Anonim, 2005) "Organik hayvancılık yapacak işletmelerdeki hayvanlar, meralara veya açık hava gezinti alanlarına veya açık alanlara erişebilmeli” ifadesi yer almaktadır. Dolayısıyla organik hayvancılık işletmelerinin yapay veya doğal mera alanlarına ihtiyacı bulunmaktadır.

Gerek yem bitkileri yetiştirilen tarlalarda, gerekse çayır ve mera alanlarında verimi ve kaliteyi olumsuz etkileyen en önemli faktörlerden birisi yabanc1 otlardır. $\mathrm{Bu}$ nedenle, kaliteli kaba yem üretiminde yabanc1 otlarla mücadele etmek gerekmektedir.

$\mathrm{Bu}$ derlemede, organik kaliteli kaba yem üretiminde yabancs ot mücadele yöntemlerine değinilecektir.

\section{Yabancı Ot ve Mücadelesi}

Kaba yem üretiminde yabancı ot tanımını yapmak istediğimizde, karşımıza iki farklı tanım çıkmaktadır. Yapay çayır mera alanları ve tarla tarımı içerisinde yem bitkisi tarımını dikkate aldığımızda, yetiştirdiğimiz tür dışındaki bütün bitkileri yabancı ot olarak tanımlamaktayı. Ancak doğal çayır mera alanlarında; hayvanların sağlığına zararlı olan, otlamak istemedikleri, hayvansal ürünlerin kalitesini bozan, çayır ve mera yönetimini zorlaştıran ve bu alanlarda gelişmesi istenilen türleri baskılayan bitkilerin tamamı yabanc1 ot olarak kabul edilir (Altın ve ark., 2005). Yukarıdaki tanımdan da anlaşılacağı üzere, doğal çayır mera alanlarında yabancı ot tanımı diğer bitkisel üretimlere göre oldukça farklı ve bir o kadar da karmaşıktır. Buna rağmen, çayır meralarda yabancı ot olarak asıl mücadele etmek istenilen hedef türler, hayvanların tüketmedikleri, hayvan sağlığına zarar veren zehirli ve dikenli türlerdir.

$\mathrm{Bu}$ noktadan hareketle organik kaba yem üretiminde yabancı otlarla mücadele iki başlık altında incelenecektir.

\subsection{Tarla tarımı içerisinde yem bitkisi yetiştiriciliğinde yabancı ot mücadelesi}

Yem bitkisi olarak değerlendirilen çok sayıda tür bulunmaktadır. Türlerin ömür uzunlukları, tohum irilikleri, gelişme yapıları (habitusları), allelopatik etkileri gibi birçok özellikleri de birbirinden farklıdır. Tüm bu farklılıklar, yem bitkisinin yabanc1 otları baskılama gücünü değiştirmekte, dolayısıyla yabancı ot mücadelesinde de farklılıkları ortaya çıkarmaktadır. Ancak, tüm türlerin yetiştiriciliğinde yabancı otlarla mücadele edilmesi gerekmektedir.

Yem bitkisi tarımında yabancı otlarla etkin mücadele etmenin ilk şartı, temiz bir tarla hazırlığıdır. Temiz tarla hazırlığında toprak işleme etkin bir yöntemdir. Yem bitkisi ekilecek tarlada ilk olarak anız bozma sürümü yapılır. Sonra yüzeysel bir ikileme işlemi yapılmalıdır (Yolcu ve Tan, 2008). Özellikle ekim öncesinde yapılan yüzeysel 
toprak işleme ile yeni çimlenmiş yabancı ot fideleri yok edilir.

Ekim nöbeti uygulanarak yabanc1 otlar kontrol altında tutulur. Yabancı otlarla iyi mücadele eden bitkilerin tarlada ön bitki olarak yetiștirilmesi büyük bir öneme sahiptir. Çapa bitkileri ve serin iklim tahılları, yem bitkileri yetiştirilecek tarlada bir y1 önce ekildiğinde yabanc1 otları baskılayabilmektedir (Serin ve Tan, 2008a). Serin iklim tahıllarının iri tohumları, güçlü fideleri, sık ekilmeleri ve allelopatik etkileriyle yabancı otları baskılama yetenekleri oldukça yüksektir. Yapılan çalışmalarda arpanın Papaver rhoeas, Veronica hederifolia, Echinochloa crus-galli, Eclipta prostrata, Agropyron repens, Avena ludoviciana, Phalaris paradoxa, Alopecurus myosuroides, Sinapis arvensis üzerinde baskılayıcı etkisi belirlenmiş, ancak arpanın allelopatik etkisinin çeşitlere göre farklılık gösterdiği bildirilmiştir (Jabran, 2017). Dhima ve ark. (2006), arpa, çavdar ve tritikalenin Echinochloa crus-galli ve Setaria verticillata'nın çimlenme gelişimini azalttığını bildirmektedir. Serin iklim tahılları dar yapraklı bitkiler olduklarından, geniş yapraklı bitkiler olan baklagil yem bitkilerinde sorun oluşturan küskütle mücadelede de ayrı bir öneme sahiptir. Örneğin, yoncada en önemli yabanc1 ot küsküttür (Acar ve Ayan, 2012). Oysaki buğday, arpa gibi buğdaygiller familyasından bitkiler küsküt için uygun konukçu bitki türleri değildir (Albert ve ark., 2008). O nedenle, küsküt probleminin görüldüğü tarlalarda, yonca gibi baklagil yem bitkileri yetiştirilmek istenildiğinde, birkaç yıl serin iklim tahılı yetiştirip, ardından yonca ve diğer baklagil yem bitkileri ekilebilir.

Temiz tarla hazırlığında örtü bitkisi yetiştiriciliğinden de faydalanılmaktadır. Örtü bitkisi, yetiştirilmek istenen yem bitkisinin ekiminden önce yeşil olarak veya herbisitle kurutularak tamamen toprağa karıştırılmakta (Dhima ve ark., 2009) veya malç olarak toprak yüzeyinde bırakılmaktadır. Organik tarımda kimyasal kullanımına izin verilmediğinden, örtü bitkisini herbisitle kurutma şansı bulunmamaktadır. Örtü bitkisi olarak yaygın olarak kışlık tahıllar ve tüylü fiğ ekilmekle birlikte, farklı bitkiler de bu amaçla kullanılmaktadır. Tüylü fiğin örtü bitkisi olarak ekildiği ve toprağa karıştırıldığı bir çalışmada, geniş yapraklı yabancı otları, buğdaygillere göre daha fazla baskıladığı belirlenmiştir. Aynı çalışmada geniş yapraklı yabanc1 otlardan Galium spurium, Chenopodium album, Plantago asiatica, Rumex japonicus ve Amaranthus retroflexus'un büyük oranda baskılandığı belirlenmiştir (Won ve ark., 2011). Üçgül türleri, yem bezelyesi, ak lüpen (Price ve
Norsworthy, 2013) de örtü bitkisi olarak değerlendirilmektedir.

Örtü bitkisi ekimi mısır, sorgum, soya gibi geniş sıra aralığında ekilen bitkilerde uygulanmaktadır (Anonymous, 2018). Misır bitkisi ile yapılan bir çalışmada bazı aromatik bitkiler (Pimpinella anisum, Foeniculum vulgare, Ocimum basilicum, Anethum graveolens, Coriandrum sativum, Petroselinum crispum, Phacelia tanacetifolia, Mentha $X$ verticillata, Origanum vulgare, Melissa officinalis) çiçeklenme öncesi dönemde yeşil olarak toprağa karıştırılmışlar ve arkasından mısır ekilmiştir. Araştırma sonucunda söz konusu bitkilerin yabancı ot gelişimini baskıladıkları belirlenmiştir. Ayrıca, Phacelia tanacetifolia ve Origanum vulgare'nin yeşil olarak toprağa karıştırıldığı parsellerden elde edilen mısır silaj verimi, diğer bitkilerin yetiştirildiği alanlardan elde edilen silaj veriminden daha yüksek bulunmuştur (Dhima ve ark., 2009).

Yem bitkilerinin yetiştirildiği dönem (tek yıllık bitkilerde bir büyüme mevsimi, çok yıllık türlerde ise birkaç y1l) içinde de yabancı otlarla mücadele etmek gerekmektedir. Bütün yem bitkilerinin yabancı otlara karşı en hassas oldukları dönem fide dönemleridir. $\mathrm{Bu}$ nedenle, yabanc1 otlarla mücadelede ilk olarak yem bitkisinin güçlü bir fide gelişimi sağlanmalıdır. Kaliteli tohumluk kullanımı, zamanında ekim, yeterli besin elementlerinin ve suyun sağlanması fidelerin daha güçlü gelişmesini sağlamaktadır.

Yetiştirilecek olan yem bitkisi türünün tohum iriliği ve ömür uzunluğu fide gelişimini etkilemektedir. Tek yıllık türlerde fide gelişimi, çok yıllık türlere göre, daha hızlı olmaktadır. Büyük tohumların çimlenmesi sonucunda ise iri fideler oluşmaktadır. Hem büyük tohumlu, hem de tek yıllık olan bezelye, fiğ, mürdümük, soya, börülce, mısır, sorgum ve serin iklim tahılları (buğday, arpa, çavdar ve tritikale) çimlendiklerinde iri fideler oluşturmaktadır. $\mathrm{Bu}$ nedenle, yabancı otlarla rekabet güçleri yüksektir. Ancak, yukarıda bahsedilen türlerin ekiminde uygulanan sira aras1 mesafe birbirinden farklı olduğundan, söz konusu türlerde yabanc1 ot mücadelesi de farklılık göstermektedir.

Bezelye, fiğ, mürdümük ve serin iklim tahılları dar sıra aralığında ekildiklerinden, sıra aralarını kolaylıkla kapatmaktadırlar. Ancak, yine de yabancı otlarla mücadele gerekebilir. Yaygın fiğ ve macar fiğinde ekimden önce yüzeysel bir sürüm yabancı otlarla mücadele için önerilirken (Serin ve Tan, 2008b, 2008c), kışlık buğdayda ise organik yetiştiricilikte bölge için uygun olan ekim oranından daha sık ekim yapılması önerilmiştir (Öztürk ve ark., 2012). 
Soya, börülce, mısır, sorgum geniş sıra aralıklarında ekildiklerinden, bu bitkilerde yabancı otlarla mutlaka mücadele edilmesi gerekmektedir. $\mathrm{Bu}$ bitkilerde yabancı ot mücadelesinde çapalama yapılmaktadır. Organik soya tarımında sık ekimin yabancı otları baskıladığı bildirilmektedir. Kuzey Carolina'da geleneksel olarak 247.000 canlı tohum/ha ekim oranı önerilirken, yapılan çalışmada yüksek verim, daha iyi yabancı ot mücadelesi için ekim oranı 556.000 canlı tohum/ha olarak önerilmiştir (Place ve ark., 2009). Ayrıca, mısır veya soya sıraları arasında başka bitkiler yetiştirilerek (canlı malç) yabancı otlarla mücadele edilebilir. Organik soya yetiştiriciliğinde, soya siraları arasina Medicago scutellata, M. polymorpha ve M. lupulina ile Trifolium subterraneum ekildiği bildirilmiştir (Acar ve ark., 2006). Başka bir çalışmada ise, ak üçgül canlı malç olarak mısır yetiştiriciliğinde kullanılmıştır. Çalışmada ayrıca, ak üçgülün mısırın fosfor alımını artırdığı da belirlenmiştir (Deguchi ve ark., 2005).

Yem bitkileri karışım halinde edildiklerinde, yalın ekimlere göre, yabancı otlarla mücadele gücü artar. Ayrıca, karışımların sağladığı başka faydalar da dikkate alındığında, genellikle karışık ekim tercih edilmektedir. Karışık ekimde beklenen faydanın sağlanması için karışıma alınan türler ve ekim oranları doğru belirlenmelidir.

Bilindiği üzere, çok yıllık yem bitkileri ilk yıl çok yavaş gelişirler. $\mathrm{Bu}$ nedenle, tesis yılında yabancı otlar daha büyük sorun oluşturmaktadırlar. Çok yıllık yem bitkileri hem tesis yılında yabancı otlarla mücadele gücünü, hem de ilk yıl elde edilen verimi artırmak amacıyla, tek yıllık hızlı gelişen bitkilerle (arkadaş bitki) birlikte ekilmektedir. Arkadaş bitkinin yabancı otlarla mücadelede başarılı olabilmesi için, arkadaş bitki olarak uygun bitki türü ve çeşidi seçilmeli, ekim oranı iyi ayarlanmalı, uygun dönemde hasat edilerek tesisten çıkarılmalıdır (Acar ve ark., 2006).

Yonca yalın ekildiğinde, arkadaş bitki olarak arpa (Erkovan ve Tan, 2009), buğday (Çoruh ve Tan, 2016), yulaf (Curan ve ark., 1993) kullanılmıştır. Yonca buğdaygillerle karışık ekildiğinde de yabancı otlarla mücadele için arkadaş bitki kullanılmıştır. Karışık ekimlerinde arkadaş bitki olarak kanola, bezelye ve İtalyan çimi (Jefferson ve ark., 2005), yulaf (Acar ve ark., 2006) arkadaş bitki olarak kullanılmıştır. Çayır üçgülü yalın ekildiğinde ise arpa (Tan ve ark., 2004; Önal Aşcı ve ark., 2010), tritikale (Acar ve ark., 2011), yem bezelyesi (Acar ve ark., 2010) ile birlikte ekilmiş, çayır üçgülü+melez üçgül+çayır köpek kuyruğu karışımı arkadaş bitki olarak arpa ile birlikte ekilmiştir (Spaner ve Todd, 2003). Yonca ve çayır üçgülünde olduğu gibi, ak üçgül de yalın ekildiğinde arpa ile birlikte ekilmiştir (Tan ve Erkovan, 2004). Görüldüğü üzere çok yıllık yem bitkileri ekiminde arkadaş bitki olarak arpa öne çıkmaktadır. Çok yıllık yem bitkilerinin arkadaş bitki ile birlikte ekilmesi sadece yabanc1 otları baskılamaz, aynı zamanda ilk yıl elde edilen verimi de artırmaktadır. Örneğin, Erzurum ekolojik koşullarında $18 \mathrm{~kg} \mathrm{da}^{-1}$ arpa ile birlikte ekilen ve arpanın süt-hamur olum döneminde hasat edilen yonca parselinden elde edilen otun içerisinde \% 1 oranında yabacı ot bulunurken, aynı dönemde hasat edilen yalın yonca parselinden elde edilen otun içinde \% 69 oranında yabancı ot bulunmuştur. Araştırmada söz konusu parsellerden tesis yılında elde edilen kuru ot verimi ise sirasiyla $508 \mathrm{~kg} \mathrm{da}^{-1}$ ve $102 \mathrm{~kg} \mathrm{da}^{-1}$ olarak belirlenmiştir (Tan ve Serin, 2004).

Arkadaş bitkinin ekim oranı önemlidir. Arkadaş bitkinin ekim oranının, yalın ekimlerinde kullanılan oranlarına göre azaltılması önerilmektedir (Tan ve ark., 2004). Örneğin, çayır üçgülü bezelye (20, 40, 60 veya 80 tohum $\mathrm{m}^{-2}$ ) ile ekildiğinde, bezelyenin ekim oranı arttıkça, bezelyede yatmanın arttığ1 ve çayır üçgülünde en fazla seyrekleşmenin 80 tohum $\mathrm{m}^{-2}$ bezelye dozunda olduğu belirlenmiştir. $\mathrm{Bu}$ nedenle, bezelyenin çayır üçgülünde arkadaş bitki olarak 40 veya 60 tohum $\mathrm{m}^{-2}$ ekim oranında ekilmesi uygun bulunmuştur (Acar ve ark., 2010). Ancak, her zaman azaltmaya gerek olmayabilir. Cupina ve ark. (2010), çayır üçgülünün ikinci y1lında ilk biçimde elde edilen kuru ot verimine arkadaş bitki olarak ekilen bezelyenin ekim oranının (30, 60 veya 90 tohum $\mathrm{m}^{-2}$ ) etkisi olmadığını belirlemişlerdir. Çayır üçgülünde yürütülen başka bir çalışmada, arkadaş bitki olarak ekilen tritikalenin uygun ekim oranı 500 veya 650 tohum $\mathrm{m}^{-2}$ (Acar ve ark., 2011) olarak belirlenmiştir ki, 650 tohum $\mathrm{m}^{-2}$ tritikale yalın ekimde kullanılan tohum oranından daha fazladır. Nitekim, Mut ve Erbaş Köse (2018), tritikaleyi yalın yetiştirdiklerinde yaklaşık 550 tohum $\mathrm{m}^{-2}$ oranında ekmişlerdir. Benzer şekilde, Erzurum ekolojik koşullarında çayır üçgülü ve ak üçgül arpa ile birlikte ekildiğinde, arpanın ekim oranını azaltmaya gerek olmadığı belirlenmiştir. Araştırmada arpanın çayır üçgülü ve ak üçgülün gelişimini baskılamasına rağmen, bitki sıklığını azaltmadığı belirlenmiştir. Çalışma sonucunda, her iki yem bitkisi türü ile birlikte ekildiğinde, arpanın ekim oranını azaltmaya gerek olmadığı (arpanın $18 \mathrm{~kg}$ $\mathrm{da}^{-1}$ ekim oranında ekilebileceği) bildirilmiştir (Tan ve ark., 2004; Tan ve Erkovan, 2004).

Arkadaş bitkinin hasat zamanı da önemlidir. Arkadaş bitkinin yem bitkisi ile olan rekabetini azaltmak için, genellikle erken hasat edilmesi önerilmektedir. Ancak, yapılan çalışmalarda hasat zamanı bakımından farklı sonuçlar elde edilmiştir. 
Örneğin, çayır üçgülü arpa ile birlikte ekildiğinde tahılın süt-hamur olum döneminde (Önal Aşcı ve ark., 2010) veya tohum hasadı için tanenin sert olum döneminde hasat edilmesi (Tan ve ark., 2004), tritikale ile birlikte ekildiğinde, tahılın süt-hamur olum döneminde hasat edilmesi (Acar ve ark., 2011), bezelye ile birlikte ekildiğinde ise bezelyede baklaların \% 70'inin normal iriliğine ulaştığ zamanda hasat edilmesi önerilmiştir (Acar ve ark., 2010). Ak üçgül arpa ile birlikte ekildiğinde, arpanın süt-hamur olum veya tane için tane olum döneminde hasat edilmesinin, ak üçgülün 2. yılında elde edilen verime etkisinin olmadı $\breve{g}_{1}$ bildirilmiştir (Tan ve Erkovan, 2004).

Arkadaş bitkinin yabancı otları baskılaması ve yem bitkisine olumsuz etkisi üzerinde, yem bitkisinin yetiştirileceği tarlanın yabanc1 ot popülasyonu (hem yabanc1 ot türü, hem de yoğunluğu) da büyük öneme sahiptir. Örneğin, Samsun'da yapılan çalışmalarda tarlada yabancı ot olarak Matricaria sp., Sinapsis arvensis ve Veronica sp. bulunduğunda, çayır üçgülü yetiştiriciliğinde arkadaş bitki olarak arpa ve tritikalenin etkili olduğu ancak, Alopecurus myosuroides ve Vicia sp. türlerinin yoğun olarak bulunduğu alanda ise, arkadaş bitkilerin yabancı otları yeterince baskılayamadığı belirlenmiştir (Önal Aşcı ve ark., 2010; Acar ve ark., 2011). Ayrıca, tarlada yabancı ot olarak Matricaria sp., Sinapsis arvensis ve Veronica sp. bulunduğunda çayır üçgülünün 450 tohum $\mathrm{m}^{-2}$, Alopecurus myosuroides ve Vicia sp türleri bulunduğunda ise 600 tohum $\mathrm{m}^{-2}$ arpa ile ekilmesi uygun bulunmuştur (Önal Aşcı ve ark., 2010). Başka bir çalışmada ise, Alopecurus myosuroides ve Vicia sp türlerinin yoğun olduğu tarlada, çayır üçgülü arkadaş bitki olarak yarı yapraklı yem bezelyesi ile birlikte ekildiğinde, bezelyenin Alopecurus myosuroides türünü baskıladığı fakat Vicia sp. türlerinde etkili olmadığı belirlenmiştir (Acar ve ark., 2010).

Çok yıllık yem bitkileri ilk y1l arkadaş bitki kullanılmadan ekilmişlerse, fide döneminde hızlı gelişen yabancı otlar da temizleme biçimi yapılarak kontrol edilmeye çalışılır. Burada biçim yüksekliğini yem bitkisine zarar vermeyecek şekilde üstten ayarlamak daha uygun olacaktır. Üretim yıllarında da biçim zamanı ayarlanarak yabanc1 otlarla mücadele edilir. Örneğin, yoncada üretim yılında yabancı otlar, genellikle ilk biçimde problem oluşturur. Yonca, yabancı otların gelişimine bakılarak, ot hasadı için uygun dönemden daha erken biçilerek yabancı otların tohum olgunlaştırması engellenir. Ancak, serin mevsim buğdaygil yem bitkilerinin erken ilkbaharda biçimi sırasında dikkatli olunmalıdır. Bilindiği üzere, serin mevsim buğdaygil bitkilerinin çiçeklenmesi için bazı türlerde sadece uzun gün yeterli iken, bazı türlerde vernalizasyon ve gün uzunluğu isteğinin karşılanması gerekmektedir. Lolium perenne, Dacytlis glomerata, Festuca pratensis, Festuca rubra, Bromus inermis, Poa pratensis, Alopecurus pratensis, Agrostis capillaris gibi bitkilerde çiçeklenmenin gerçekleşmesi için vernalizasyon ve arkasından uzun günlerin sağlanması gerekmektedir. Vernalizasyonun etkisi lokaldir, yani vernalize olan kardeş için geçerlidir. Vernalizasyondan sonra gelişen diğer kardeşlere aktarılmaz (Heide, 1994). Bu nedenle, vernalize olmuş kardeşte gövdenin meristem dokusu uzaklaştırılırsa bu kardeşte çiçeklenme oluşmaz ve bitkide biçimden sonra gelişen yeni kardeşler de çiçeklenemez. $\mathrm{Bu}$ nedenle, buğdaygillerde ve buğdaygillerin yer aldığı karışımlarda biçim zamanı ve biçim yüksekliği ayarlanırken daha dikkatli olunması gerekmektedir.

\section{2. Çayır meralarda yabancı ot mücadelesi}

Türkiye'de yaklaşık 14.6 milyon ha çayır mera alanı bulunmaktadır. $\mathrm{Bu}$ alanların 1.4 milyon hektarı çayır, 13.2 milyon hektarı ise mera alanıdır (Altın ve ark., 2011a). Türkiye'deki doğal çayır ve mera alanlarının bitki örtüsü, bulunduğu ekosistem içinde doğal olarak oluştuğundan, çok sayıda farklı tür bir arada bulunmaktadır. Bu durum, üzerinde otlayan hayvanlar için dengeli ve sağlıklı besin maddeleri sağlamasına karşın, bazı türler de yabancı ot olarak karşımıza çıkarmaktadır.

Çayır ve mera alanlarının hem toprak özellikleri, hem de faydalanma durumları farklıdır. Çayır ve taban mera alanlarında, bilindiği üzere, taban suyu seviyesi yüksektir. Bu nedenle söz konusu alanlarda zaman zaman Juncus sp., Carex sp. türlerinin istilasına rastlanılmaktadır. Bu türlerle mücadele edebilmek için, öncelikle drenaj probleminin çözülmesi gerekmektedir. Ayrıca, taban suyu seviyesi düşürüldüğünde kaliteli yem bitkileri daha kuvvetli gelişme şansı bulacaktır. Sürmen (2010), Samsun Bafra'da Juncus effusus'un yoğun olarak bulunduğu taban merada farklı 1slah işlemleri uygulamıștır. Araştırmada uygulanan 1slah işlemlerinin botanik kompozisyonda Juncus effusus oranını önemli derecede etkilediği belirlenmiştir. Çalışma sonuçları organik tarıma uygunluk çerçevesinde değerlendirildiğinde, biçme, freze çekme, biçme+freze çekme işlemlerinin Juncus effusus türüyle mücadelede başarılı olduğu görülmüştür.

Çayır mera alanlarında iyi cins yem bitkilerinin güçlü gelişimini sağlamak, yabancı otları baskılamaktadır. Bu nedenle, toprak pH's1 ve besin elementi içeriği düzenlenmelidir (Green ve ark., 2006). Genel olarak toprak pH'sının 6'dan düşük olduğu çayır meralarda kireçleme önerilmektedir (Aydın ve Uzun, 2002). Çayır mera alanlarında 
otlatma ve biçimin düzenlenmesi, mekanik mücadele, biyolojik yöntemlerin kullanılması ve bazı mera 1slah yöntemleri ile yabancı otlarla mücadele edilebilir.

Meraların doğru kullanılmasında ilk şart mera yönetim ilkelerine uyulmasıdır. Türkiye meralarında maalesef yönetim ilkelerine uyulmamaktadır. Meralarda otlatma yoğunluğu ile yabancı ot varlığı arasında ilişki bulunmaktadır. Meraların otlatma derecesi mera toprağının sıkışmasını etkilemektedir. Nitekim, Kastamonu ili Taşköprü ilçesinde 12 doğal merada, otlatma az olduğunda bitki ile kaplı alan artmıştır. Ancak, bitki ile kaplı alan içinde mera durumu belirlemede değerlendirilen kaliteli yem bitkilerinin (azalıcı+çoğalıcı bitki) oranı, genellikle düşük kalmıştır (İspirli ve ark., 2016). Bu durum, merada yabancı ot olarak değerlendirilen türlerin otlatma baskısı az olduğunda arttığı anlamına gelmektedir. Ağır otlatmanın da merada yabancı otların artmasına neden olduğu bilinmektedir. Nitekim, Erzurum'da yürütülen bir çalışmada korunan, ağır otlatılan ve sürülüp terkedilen mera alanlarının mera kalite dereceleri belirlenmiştir. Araştırmada en yüksek mera kalite derecesi korunan merada belirlenirken, bunu ağır otlatılan mera takip etmiştir (Çomaklı ve ark., 2012). Dolayısıyla, meraların ağır otlatılması sonucu primer süksesyonun yok olup sekonder süksesyonun gelişmesi, meralarda yabancı ot problemini artırmaktadır. Doğal mera alanlarının öncelikle, mera yönetim ilkelerine uygun olarak, zamanında ve kapasitesinde otlatılması gerekmektedir.

Çayır meralarda yetişen yem değeri olmayan veya meranın niteliğini azaltan ağaç, çalı gibi odunsu türler kesme, kökleme, budama, buldozer geçirme, zincir çekme gibi mekanik yöntemlerle baskılanabilir. Otsu ve ince gövdeli çalılar biçme makineleriyle biçilerek kontrol altına alınabilir. Doğal çayır meralarda seyrek olarak bulunan otsu yabancı otlar ve ince gövdeli çalılar çapalama ile yok edilebilir (Altın ve ark., 2005).

Çayır ve meralarda tek yıllık yabancı otlarla mücadele amacıyla erken biçim ve erken otlatma uygulanabilmektedir. Tek yıllık bitkiler ilkbaharda çok yıllık bitkilere göre daha hızlı gelişmekte ve daha erken çiçeklenmektedirler. Erken biçim tek yıllık bitkilerde tohum olgunlaştırmadan önce uygulanmalıdır. Örneğin Mut (2009), Samsun ekolojik şartlarında sekonder bir merada erken biçim işlemini, ilkbaharda erken gelişen tek yıllık buğdaygillerde çiçek topluluğunun görülmeye başladığı dönemde uygulamıştır. Çalışmada erken biçim uygulamasının tek y1llık buğdaygilleri (Vulpia ciliata, Bromus tectorum, Bromus squarrosus) azalttığı, çok yıllık buğdaygilleri (Poa trivialis, Dactylis glomerata, Alopecurus myosuroides) arttırdığı belirlenmiştir. Aynı çalışmada erken biçim ile ahır gübresi birlikte uygulandığında ise, meradan elde edilen baklagil kuru ot verimi artmıştır.

Ayrica, otlatma mevsimi sonunda, hayvanların otlamadığı geride kalan bitkilerin de temizleme biçimi ile meradan uzaklaştırılması, gelecek y1llarda merada yabanc1 ot probleminin artmasinı engelleyecektir.

Yarı kurak bölgelerde, meralarda tek yıllık yabanc1 otlarla mücadele amaciyla dinlendirerek münavebeli otlatma sisteminden yararlanılabilir. $\mathrm{Bu}$ sistemde, yabanc1 otlarla mücadele edilmek istenilen mera alanı otlatma mevsiminin başında ağır bir şekilde otlatılır. Sonraki iki yılda ise mera, bitkilerinin kendini toplamasına izin vermek için, otlatma mevsiminin ortasında otlatılmaya başlanır (Altın ve ark., 2011a).

Meralarda yabancı otlarla mücadelede otlayan hayvan türü de etkili olmaktadır. Sığır ve atlar çoğunlukla buğdaygilleri otlarken, koyunlar geniş yapraklı otları tercih ederler. Keçiler ise çok miktarda geniş yapraklı ot tüketirken, fazla miktarda çalı ve buğdaygil otlayabilmektedirler (Altın ve ark., 2011b). Sığır ve koyunlar öncelikle bitkilerin yeşil yapraklarını tercih ederlerken, keçiler ise bitkilerin çiçek ve tohum kısımlarını tercih etmektedirler. Ayrıca, keçiler Cirsium arvense, Centaurea solstitialis, Rumex spp., Rubus spp., Rosa spp. ve Genista spp. türlerini diğer hayvan gruplarına göre daha fazla otlamaktadırlar (Uzun ve ark., 2015).

Bazı böceklerden de meralarda yabanc1 ot kontrolünde yararlanılabilir. Örneğin, Hypericum perforatum ile mücadelede Chrysolina quadrigemina ve Chrysolina hyperici türleri, Centaurea diffusa ile mücadelede Urophora affinis, Tribulus terrestris ve Tribulus cistoides ile mücadelede Microlarinus lareynii, Carduus nutans ile mücadelede Rhinocyllus conicus, Senecio jacobaea ile mücadelede Longitarsus flavicornis, Longitarsus jacobaeae, Cochylis atricapitana türlerinin kullanıldığı belirtilmiştir (Atay ve ark., 2015). Doğu Akdeniz çayır meralarında yürütülen bir çalışmada, Euphorbia sp. türlerinde beslenen Hyles euphorbiae ve Denticera divisella türü böceklerin biyolojik mücadele bakımından ümitvar olduğu belirlenmiştir (Uygun ve ark., 1996).

\section{Sonuçlar}

Organik hayvancılıkta, hayvanların beslenmesinde kullanılan kaba yemlerin de organik olarak üretilmiş olması gerekmektedir. Organik bitkisel üretimde herbisit kullanımına izin verilmemektedir. 
$\mathrm{Bu}$ nedenle, kaba yem üretiminde önemli sorunlardan birisi olan yabancs ot probleminin kimyasal kullanmaksızın kontrol altında tutulması gerekmektedir. Tarla tarımı içerisinde yem bitkileri yetiştiriciliğinde farklı yöntemlerle yabancı otlarla mücadele edilmekle birlikte, en etkin yöntem aslında temiz tarlaya ekim yapmaktır. Yem bitkisi tarımında ön bitki olarak tahıl ve çapa bitkilerinin yetiştirilmesi, ekimden önce yüzlek bir sürüm ile yabanc1 ot fidelerinin yok edilmesi, temiz tarla hazırlığında etkin yöntemlerdir. Bu anlamda, ekim nöbeti planlaması yapılarak, tahıl veya çapa bitkisi yetiștiriciliğinden sonra yem bitkisi ekilmesi uygun olacaktır. Çok yıllık yem bitkilerinde ise arkadaş bitki ile birlikte ekim, yabancı otla mücadelede etkin bir yöntemdir. Mera alanlarında ise, mera yönetim ilkelerine uyulması ilk şarttır. Otlatmanın doğru şekilde planlanması ile yabancı otlarla mücadele daha kolay olacaktır. Ayrıca, uygun mera 1slah yöntemleriyle yabanc1 otlarla mücadele edilebilmektedir. Bunlara ilaveten otlatma mevsimi sonunda, hayvanların otlamadığg bitkilerin de tohum dökmeden önce biçilerek meradan uzaklaştırılması, gelecek yıllarda merada yabanc1 ot probleminin artmasını engelleyecektir.

\section{Kaynaklar}

Acar, Z., Önal Aşcı, Ö., Ayan, İ., Mut, H., Başaran, U., 2006. Yembitkilerinde karıșık ekim sistemleri. Ondokuz Mayıs Üniversitesi Ziraat Fakültesi Dergisi, 21(3): 379-386

Acar, Z., Önal Aşcı, Ö., Başaran, U., Ayan, İ., Mut, H., 2010. Pea companion crop for red clover establishment. Turkish Journal of Field Crops, 15(2): 114-122.

Acar, Z., Önal Așcı, Ö., Başaran, U., Ayan, İ., Mut, H., 2011. Can triticale be used as a companion crop with red clover? Turkish Journal of Agriculture and Forestry, 35(3): 235-245.

Acar, Z., Ayan, İ., 2012. Yem Bitkileri Kültürü (Genişletilmiş 3. Bask1). Ondokuz Mayıs Üniversitesi, Ziraat Fakültesi Ders Kitab1, No: 2, Samsun.

Açıkbaş, S., Özyazıcı, G., Özyazıcı, M.A., Turan, N., 2017. Current status of organic forage crop production in Turkey. International Conference on Multidisciplinary, Engineering, Science, Education and Technology (IMESET'17 Baku), July 12-14, Baku, Azerbaijan, p. 58

Albert, M., Belastegui-Macadam, X.M., Bleischwitz, M., Kaldenhoff, R., 2008. Cuscuta spp: "Parasitic Plants in the Spotlight of Plant Physiology, Economy and Ecology". In: Lüttge U., Beyschlag W., Murata J. (Eds), Progress in Botany. Progress in Botany, Springer, Berlin, Heidelberg, Vol 69, pp. 267-277.

Altın, M., Gökkuş, A., Koç, A., 2005. Çayır Mera Islahı. Tarım ve Köyişleri Bakanlığı, Tarımsal Üretim ve Geliștirme Genel Müdürlüğü, Ankara.
Altın, M., Gökkus, A., Koç, A., 2011a. Cayır ve Mera Yönetimi. 1. Cilt (Genel İlkeler). Tarım ve Köyişleri Bakanlığı, Tarımsal Üretim ve Geliştirme Genel Müdürlüğü, Ankara.

Altın, M., Gökkuş, A., Koç, A., 2011b. Çayır ve Mera Yönetimi. 2. Cilt (Temel İlkeler). Tarım ve Köyişleri Bakanlığı, Tarımsal Üretim ve Geliştirme Genel Müdürlüğü, Ankara.

Anonim, 2005. Organik Tarımın Esasları ve Uygulanmasına İlişkin Yönetmelik. 10.06.2005 tarih 25841 say1l1 Resmi Gazete.

Anonim, 2018. Organik Tarım İstatistikleri. (https://www.tarim.gov.tr/Konular/Bitkisel-Uretim/ Organik-Tarim/Istatistikler), (Erişim tarihi: 25.10.2018).

Anonymous, 2018. Cover Crops and No-till Management for Organic Systems. (https://www.sare.org/ Learning-Center/SARE-Proj ect-Products/NortheastSARE-Project-Products/ Co ver-Crops-and-No-TillManagement-for-Organic-Sy stems), (Erișim tarihi: 25.10.2018).

Atay, T., Asav, Ü., Önen, H., Kara, K., 2015. İstilacı yabanc1 otlarla biyolojik mücadele. (Ed: . H. Önen), Türkiye İstilacı Bitkiler Kataloğu, Ankara, s. 81-118.

Aydın, İ., Uzun, F., 2002. Cayır-Mera Amenajmanı ve Islahı. Ondokuz Mayıs Üniversitesi, Ziraat Fakültesi Ders Kitabı, No: 9, Samsun.

Cupina, B., Krstic, D., Mikic, A., Eric, P., Vuckovic, S., Pejic, B., 2010. The effect of field pea (Pisum sativum L.) companion crop management on red clover (Trifolium pratense L.) establishment and productivity. Turkish Journal of Agriculture and Forestry, 34(4): 275-283.

Curan, B.S., Kephart, K.D., Twidwell, E.K., 1993. Oat companion crop management in alfalfa establishment. Agronomy Journal, 85(5): 998-1003.

Çomaklı, B., Öner, T., Daşc1, M., 2012. Farklı kullanım geçmișine sahip mera alanlarında bitki örtüsünün değişimi. Iğdır Üniversitesi Fen Bilimleri Enstitüsü Dergisi, 2(2): 75-82.

Çoruh, I., Tan, M., 2016. The effects of seeding time and companion crop on yield of alfalfa (Medicago sativa L.) and weed growth. Turkish Journal of Field Crops, 21(2): 184-189.

Deguchi, S., Uozimi, S., Tawaraya, K., Kawamoto, H., Tanaka, O., 2005. Living mulch with white clover improves phosphorus nutrition of maize of early growth stage. Soil Science and Plant Nutrition, 51(4): 573-576.

Dhima, K.V., Vasilakoglou, I.B., Eleftherohorinos, I.G., Lithourgidis, A.S., 2006. Allelopathic potential of winter cereals and their cover crop mulch effect on grass weed suppression and corn development. Crop Science, 46(1): 345-352.

Dhima, K.V., Vasilakoglou, I.B., Gatsis, Th.D., PanouPhilotheou, E., Eleftherohorinos, I.G., 2009. Effects of aromatic plants incorporated as green manure on weed and maize development. Field Crops Research, 110(3): 235-241. 
Erkovan, H.İ., Tan, M., 2009. The effects of companion crop on alfalfa seed yield. Journal of Food, Agriculture \& Environment, 7(3\&4): 312-315.

Green, J.D., Witt, W.W., Martin, J.R., 2006. Weed Management in Grass Pastures, Hayfields, and Other Farmstead Sites. (http://www2.ca.uky.edu/agcomm/ pubs/agr/agr172/agr172.pdf), (Erişim tarihi: 25.10.2018).

Heide, O.M., 1994. Control of flowering and reproduction in temperate grasses. New Phytologist, 128(2): 347-362.

İspirli, K., Alay, F., Uzun, F., Çankaya, N., 2016. Doğal meralardaki vejetasyon örtüsü ve yapısı üzerine otlatma ve topografyanın etkisi. Türkiye Tarımsal Araşttrmalar Dergisi, 3(1): 14-22.

Jabran, K., 2017. Manipulation of Allelopathic Crops for Weed Control. Springer International Publishing AG, Switzerland.

Jefferson, P.G., Lyons, G., Pastl, R., Zentner, R.P., 2005. Companion crop establishment of short-lived perennial forage crops in Saskatchewan. Canadian Journal of Plant Science, 85(1): 135-146.

Mut, H., 2009. Sürülüp terkedilen bir merada farklı 1slah yöntemlerinin etkinliklerinin belirlenmesi. Doktora tezi, Ondokuz Mayıs Üniversitesi Fen Bilimleri Enstitüsü, Samsun.

Mut, Z., Erbaş Köse, Ö.D., 2018. Tritikale genotiplerinin tane verimi ve bazı kalite özellikleri. Anadolu Tarım Bilimleri Dergisi, 33(1): 47-57.

Önal-Aşc1, O., Acar, Z., Başaran, U., Ayan, İ., Mut, H., 2010. Barley companion crop management in red clover establishment. African Journal of Agricultural Research, 5(1): 045-054.

Özen, N., Şayan, Y., Ak, İ., Yurtman, İ.Y., Polat, M., 2010. Hayvansal üretim-çevre ilișkileri ve organik hayvanc1lık. Türkiye Ziraat Mühendisliği 7. Teknik Kongresi, 11-15 Ocak, Ankara, s. 687-706.

Öztürk, A., Bulut, S., Yıldız, N., Karaoğlu, M.M., 2012. Effects of organic manures and non-chemical weed control on wheat: I-Plant growth and grain yield. Tarım Bilimleri Dergisi, 18(1): 9-20.

Place, G.T., Reberg-Horton, S.C., Dunphy, J.E., Smith, A.N., 2009. Seeding rate effects on weed control and yield for organic soybean production. Weed Technology, 23(4): 497-503.

Price, A.J., Norsworthy, K., 2013. Cover crops for weed managemenet in southern reduced-tillage vegetable cropping systems. Weed Technology, 27(1): 212-217.

Serin, Y., Tan, M., 2008a. Yem bitkileri tesislerinin kurulması. (Ed: Y. Serin), Yem Bitkileri ve Meraya
Dayalı Hayvancılık Ĕ̆itimi, Erciyes Üniversitesi Yayin No: 160, Kayseri, s. 26-50.

Serin, Y., Tan, M., 2008b. Yerli fiğ tarımı. (Ed: Y. Serin), Yem Bitkileri ve Meraya Dayalı Hayvancılık Eğitimi, Erciyes Üniversitesi Yayın No: 160, Kayseri, s. 91106.

Serin, Y., Tan, M., 2008c. Macar fiği tarımı. (Ed: Y. Serin), Yem Bitkileri ve Meraya Dayalı Hayvancillk Eğitimi, Erciyes Üniversitesi Yayın No: 160, Kayseri, s. $107-117$.

Spaner, D., Todd, A.G., 2003. The impact of underseeding barley (Hordeum vulgare L.) on timothy (Phleum pratense L.)-clover (Trifolium pratense L.; Trifolium hybridum L.) forage production in a cool maritime climate. Journal of Agronomy \&Crop Science, 189(5): 273-279.

Sürmen, M., 2010. Orta Karadeniz Bölgesinde kofa (Juncus effusus L.) istilasına uğrayan taban meralar için uygun 1slah yöntemlerini Belirlenmesi. Doktora Tezi, Atatürk Üniversitesi Fen Bilimleri Enstitüsü, Erzurum.

Tan, M., Erkovan, H. İ., 2004. Using a companion crop of barley to improve white clover production in the highlands of Turkey. New Zealand Journal of Agricultural Research, 47(2): 219-224.

Tan, M., Serin, Y., 2004. Is the companion crop harmless to alfalfa establishment in the highlands of east Anatolia? Journal of Agronomy and Crop Science, 190(1): 1-5.

Tan, M., Serin, Y., Erkovan, H.İ., 2004. Effects of barley as a companion crop on the hay yield and plant density of red clover and the botanical composition of hay. Turkish Journal of Agriculture and Forestry, 28(1): 35-41.

Uygun, N., Koç, N.K., Uygur, F.N., Karaca, İ., Uygur, S., Tekeli, N.Z., Küsek, M., Aksoy, A., 1996. Doğu Akdeniz Bölgesi Çayır-mera Alanlarındaki Yabanciot Türleri ve Doğal Düşmanlarının Saptanmas1 Üzerine Araştırmalar. Tübitak Proje Sonuç Raporu, Proje No: TOAG, 988/DPT.

Uzun, F., Garipoğlu, A.V., Dönmez, H.B., 2015. Mera yabancı otlarının kontrolünde keçilerin kullanımı. Uluslararası Tarım ve Yaban Hayatı Bilimleri Dergisi, 1(1): 40-50.

Won, O-J, Uddin, Md.R., Pyon, J-Y., 2011. Herbicidal activities and crop injury of hairy vetch residues. Korean Journal of Weed Science, 31(2): 175-182.

Yolcu, H., Tan, M., 2008. Organik yem bitkileri yetiştiriciliği. Atatürk Üniversitesi Ziraat Fakültesi Dergisi, 39(1): 145-150. 